
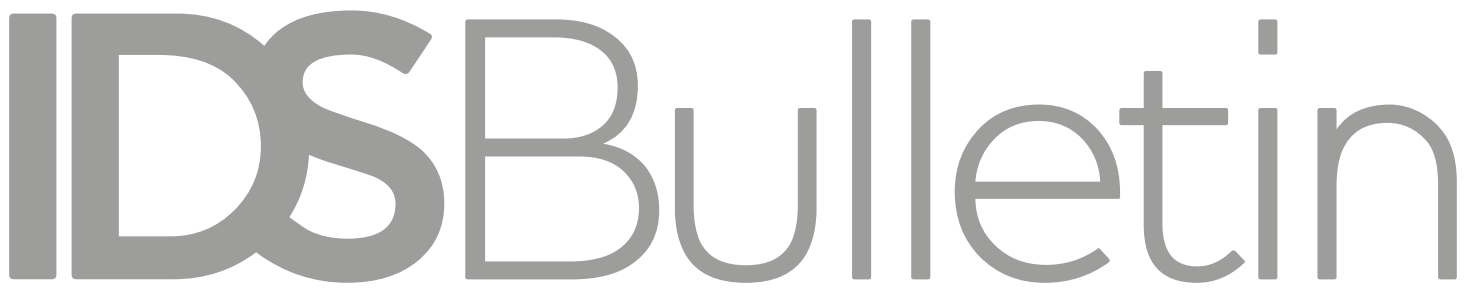

Transforming Development Knowledge

ARCHIVE COLLECTION

Volume 49 | Number 1A | April 2018

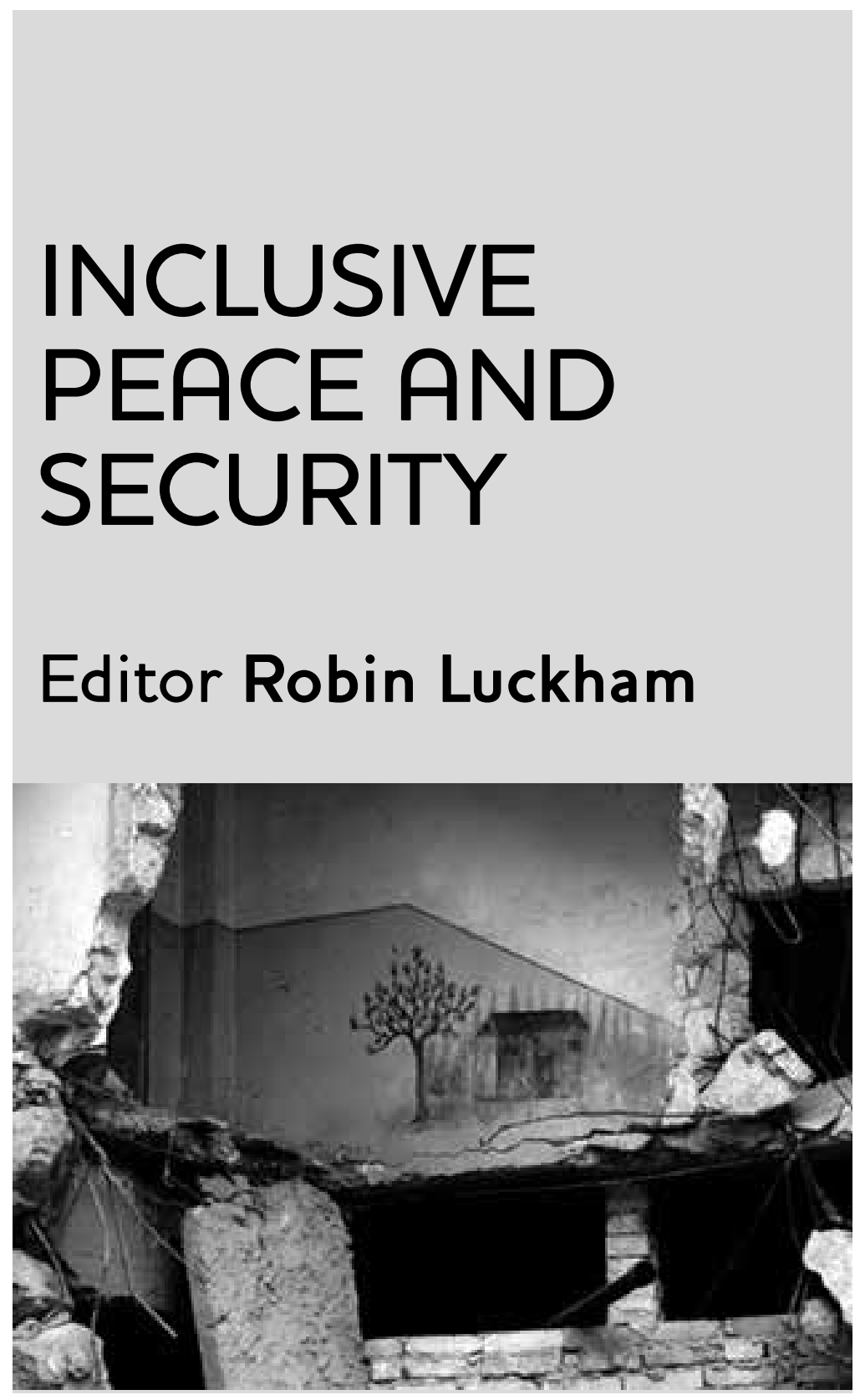




\section{Contents}

From Disarmament and Development to Inclusive Peace and Security:

Four Decades of IDS Research

Robin Luckham

Article first published April 2018, IDSB49.1A

Peace and Development

Willy Brandt

Article first published October 1985, IDSB16.4

Editorial: Disarmament and Development - the International Context

Robin Luckham

Article first published October 1985, IDSB16.4

Globalism Versus Villagism: Food Security and Environment at National and International Levels

Susanna Davies and Melissa Leach

Article first published July 1991, IDSB22.3

War and Famine in Africa

Alex de Waal

Article first published October 1993, IDSB24.4

Insecurity, Conflict and the New Global Disorder

Susan Willett

Article first published May 2001, IDSB32.2

Peace Through Agrarian Justice

Paul Richards and Khadija Bah

Article first published June 2005, IDSB36.2

'Security from Below' in Contexts of Chronic Violence

Alexandra Abello Colak and Jenny Pearce Article first published March 2009, IDSB40.2

Gendering the New Security Paradigm in Sri Lanka

Neloufer de Mel

Article first published March 2009, IDSB40.2

Researching the Gendered Silences of Violence in El Salvador

Mo Hume

Article first published May 2009, IDSB40.3

Quantitative Methods in Contexts of Everyday Violence

Patricia Justino, Jennifer Leavy and Elsa Valli Article first published May 2009, IDSB40.3

Crime and Social Cohesion in the Time of Crisis: Early Evidence of Wider

Impacts of Food, Fuel and Financial Shocks

Naomi Hossain

Article first published September 2009, IDSB40.5

\section{Social Contracts, Networks and Security in Tropical Africa Conflict States:}

An Overview

David K. Leonard

Article first published January 2013, IDSB44.1

This article has been reissued as part of IDS Bulletin Archive Collection Vol. 49 No. 1A April 2018: 'Inclusive Peace and Security'; the Introduction is also recommended reading. 


\title{
Social Contracts, Networks and Security in Tropical Africa Conflict States: An Overview
}

\author{
David K. Leonard
}

Abstract In this IDS Bulletin we present fieldwork from articles covering the Democratic Republic of the Congo, Côte d'lvoire, Sierra Leone, Mozambique and Somalia to show that assumptions derived from the classical social contract theorists frequently lead the international community astray as it attempts to rebuild these African states. The historical social contract for most Africans is not between the state and individuals but with communities. When it comes to security, there are two contracts and two bargains to consider instead of the single one of classical presumptions. The contracts are (i) community governance structures with local families; and (ii) the state with community governance systems, with supplemental ties to individuals. The bargains are (iii) the regime with the military; and (iv) the state with the international community. The military is frequently a source of predation on communities rather than of protection. The dynamics of these contracts and bargains can be in conflict with one another, leading to a situation where governance is multilevel and networked. The presence and importance of international actors in the networks changes policies and indirectly affects politics, but it does not threaten the integrity of the state as an institution itself, which instead is rooted in the processes of the other three compacts.

\section{Introduction}

When a county descends into violent domestic conflict, obviously its security is challenged. But the threat is not only to the security of the state or even to the physical protection of its citizens from violent aggression. As long ago as the English Civil War philosophers recognised that conflicts and other human acts that lead to a significant diminishment in other aspects of a community's wellbeing also shorten lives and thus are dangers to human security as well (Hobbes 1939 [1651]). Thus the threats and conflicts to be considered include not only violence itself but also ones to the resources and livelihoods on which communities are dependent. In the communities most affected by the civil wars in the Democratic Republic of the Congo (DRC), Mozambique, ${ }^{1}$ Sierra Leone and Somalia modern medicine disappeared, the future livelihoods of young people were

diminished when their education was disrupted, and malnutrition increased, such that in Sierra Leone, for example, children even died from a lack of salt (Leonard and Samantar 2011; Mushi 2012; Vincent 2012). These casualties of war are as fatal as the more obvious wounds produced by bullets and cutlasses. Even though Thomas Hobbes did not feel a government owed its citizens prosperity or justice, he did feel that a state that could not protect its subjects from lifethreatening insecurities such as these had no right to expect their obedience.

All governance is co-produced. Even if the law assigns sovereignty and suzerainty to one actor, that law is but one of the multiple resources that are needed for effective rule. And different actors possess those varied resources and supply them with greater or lesser degrees of compliance. For example, it matters whether taxes are paid willingly or evaded (Liebermann 2003). And even the lowliest workers may provide their labour enthusiastically or reluctantly (Barnard 1968 [1938]). Thus the effectiveness of all governments relies upon numerous actors at multiple levels within and beyond the state, connected to one another and the various functions of governance through complex and divergent networks (De Herdt 2011).

IDS Bulletin Volume 44 Number 1 January 2013 @ 2013 The Author. IDS Bulletin @ 2013 Institute of Development Studies Published by Blackwell Publishing Ltd, 9600 Garsington Road, Oxford OX4 2DQ, UK and 350 Main Street, Malden, MA 02148, USA 
If all governance systems are multilevel and networked to some degree, this reality is even more pronounced for countries that are emerging from prolonged periods of civil violence. In this research we have been concerned with the subset of conflict and postconflict countries located in Tropical Africa. And scholars have long remarked on the unusually large gap between what they have called 'juridical' and 'empirical' sovereignty in parts of that region; the international system grants the privileges of statehood (including international legal recognition and the last word over development assistance) to many countries that in fact are unable to exercise the monopoly over their full territory of the legitimate exercise of force that the concept of statehood requires (Jackson and Rosberg 1982; Katzenstein 1996; Weber 1947).

When a conflict or post-conflict country is unable to exercise 'empirical sovereignty', no one institution or even set of institutions is in charge. Authority is negotiated in complex and fluid sets of relationships between institutions that range from peasant villages to the metropoles of the industrial world. Whether or not the erosion of sovereignty in Africa is judged to be good or bad, it is a practical reality and must feature prominently in any attempts to understand and improve conflict management on the continent. The question therefore is not whether or not a particular type of sovereignty should exist but what new concepts can be proposed to better fit the current situation and improve it. Networks are one of those concepts.

The networks governing a country gripped in conflict or recently emerging from it will include not only its national government and its key economic and military actors but also other countries, international organisations, nongovernmental organisations (NGOs) and local level systems of governance. The former, national set of actors will have lost power and coherence, sometimes to the extent of threatening the collapse of the state itself, which opens the way for a much more significant role for the latter set. In this era of United Nations and regional peacekeeping missions and of bilateral and multilateral development assistance, the impact of internationals is widely acknowledged. In addition, however, a key finding of recent research (including our own) is that local-level systems of governance (including churches) generally are the key building blocks of social order in a post-conflict situation - for they usually were the only units managing and resolving disputes during the conflict period (Manor 2007; Bastian and Luckham 2003).

Neither the diffusion of core responsibilities in conflict states to both local and transnational non-state actors nor attempts to build state capacity directly are likely to slow or halt; neither are the fundamental tensions between the two trends likely to dissipate. As such, we must attempt to understand the implications of networked governance for institution-building in weak and fragile states.

We start by using social contract theory to look at the local-level building blocks for the reconstruction of social order and then turn to an examination of the changes and operation of the other networks engaged in governance.

\section{Local governance and the social contract}

Local governance structures most often have undergone considerable change during the conflict - for example, inequalities become larger, patronage more prominent, and the influence of the 'purveyors of violence' greater (Leonard and Samantar 2011). Thus the 'building blocks for peace' are not reflected accurately any longer in the classical anthropology texts on the social systems in question. A correct understanding of the evolution of these 'primary' governance systems under conflict and what can be expected of them subsequently is fundamental to the success of efforts to create peace and rebuild general social order.

African states that have collapsed into prolonged violent conflict severely test the ways of thinking used by those who want to help restore their populations to security. Those who populate the international organisations and donor agencies who come forward to provide assistance have never lived for long themselves in such conditions - certainly they didn't keep their families with them. And the same is true of the academics and consultants who advise them. The instinctive response of internationals is to recreate the state as it has existed in Europe since the 1648 Treaty of Westphalia. The international community has helped to prevent the complete collapse of some states, but without 
necessarily creating durable conditions for the efficient performance of the whole political system. It sometimes has helped some regimes extend their control over large territories but frequently has not yet succeeded in stabilising the various internal systems of governance that really sustain the state. Thus, on the basis of this project's fieldwork in the DRC, Côte d'Ivoire, Mozambique, Sierra Leone and the former Somalia, we submit that the international community is struggling with inadequate conceptual tools.

Generally when Westerners confront collapsed states in Africa, Thomas Hobbes and the social contract are in the background. They presuppose that the structures of the central state must be restored in the first stages of any solution, for, as Hobbes had it, life without it is 'nasty, brutish and short' (Hobbes 1939 [1651]). ${ }^{2}$ Also, they implicitly assume that the state must have failed ${ }^{3}$ because the social contract it had with its citizens has been broken and that the recreation of order will require its restoration (multiple conversations with donor staff; OCDE 2008).

Neither of these assumptions is wholly without merit. But we will show that they need to be reformulated to meet the conditions of contemporary post-conflict Africa. First, Hobbes was right that states are capable of providing the highest levels of human security and that in their absence predatory violence by competing armed groups is likely. But some states themselves create predation and insecurity and there are non-state forms of governance that can provide better than they do for safety and economic development. The DRG, Sierra Leone and Somalia all have been subjected to extreme predation by the state at certain periods in the last quarter of a century and many parts of Somalia demonstrate alternative forms of governance today (Kamara 2010; Leonard and Samantar 2011; Little 2003; Menkhaus 2006; Prunier 2009).

Second, states do need legitimacy if they are to succeed. The Zaire phase of Congo's history illustrates the point well - without a normative underpinning, the need for coercive or material inducements for compliance spiralled upward until the resources to provide them were exhausted (Etzioni 1964). Zaire probably was no more corrupt than a number of other states that have survived but, unlike them, in its last 20 years it was seriously deficient in its normative claim on the obedience of its citizens (Young and Turner 1985). As a result, it collapsed when challenged in the aftermath of the Rwanda genocide.

The 'social contract' is a thought experiment, whereby we ask when people would agree to cede authority (i.e. the obligation to obey) to a governing body in return for the social order and other benefits it might provide. The classic social contract theorists (Hobbes, Locke, Rousseau, Kant) did not posit that such an agreement was an historical act; for them it was simply a philosophical device. Nonetheless, their thought is based on clear assumptions about how humans behave, on what would lead them to consider authority legitimate, and thus on the principles from which a stable political order would need to be (re)constructed. ${ }^{4}$ Most important for our purposes they assumed that the state was based on a single 'social contract', which in principle could have been consummated between relatively equal, individual citizens. In this Overview we will show that security in the contemporary African state is actually founded on two contracts $^{5}$ and two bargains, in which the key actors are unequal groups rather than autonomous individuals. ${ }^{6}$ Contracts and bargains both are based in exchange, but contracts come to be valued for their own sake and thus create stable obligations, whereas bargains exist only so long as they produce immediate benefits for all parties.

\section{The community contract}

The fundamental social contracts in Africa are not between the state and individuals alone but by individuals with their communities and by communities with the state. Of course the African state in its contemporary configuration, save for Ethiopia, was a colonial creation and thus came into existence through external force. The colonial state could not be efficiently maintained on coercion alone, however, even with superior military technology; some normative compliance was needed as well. (Significant material inducements were not even considered.) An implicit contract therefore was struck between local 'traditional' leaders (either existing or newly created) whereby they would lead their communities in complying with the writ of the state and the colonial power would protect these authorities from any local 
challenges (Oliver and Fage 1966). In this way a necessary modicum of 'traditional' legitimacy was captured in support of a 'legal-rational' state, to use Max Weber's terms (Weber 1947). In most of Africa this community sanction continues to underwrite the authority of the state at the local level outside the major towns, even where 'traditional' rulers have been supplanted by appointive or democratic systems of governance. Mahmood Mamdani argues that this colonial legacy divides African populations between rural subjects and urban citizens (Mamdani 1996). In Congo, Côte d'Ivoire and Sierra Leone it is clear that many town dwellers and most elites do feel a powerful, unmediated commitment to their contemporary states, which has given these countries territorial resilience (and which was surprising to many external observers of the DRC in the Congo Wars). And legally Africans today are bound to their states as individuals. Nonetheless, the informal reality of the community contract and its mediated relationship with the state remains, for non-elite urban Africans are still subject to the authority of their rural communities of origin if they wish to retain land rights there (as most do).

The point then is that the social contract with the state is a mediated one for most Africans in most countries. They owe allegiance to their community and the community has a contract with the state. Today the latter contract continues to provide support for the community's governance structure and usually would involve its physical security, roads, and access to education and modern health care as well. In post-conflict situations the 'terms of exchange' for the contract will have slipped, however, so that just physical security is enough to assure the allegiance of the community's governance structure.

The nature of the community social contract is quite important as well. As Mark Button suggests, social contracts are not self-enforcing. They require supporting cultural values and institutions, which will be built in interaction with the contract itself (Button 2008). Thus the local contract has implications far beyond the community itself and powerfully shapes the discourse in the national political system as well. Authority at the local level is closely linked to control of land. In most of Africa peasants work their own land, but they do not have individually transferable ownership of it. Instead they have use rights (usufruct in Latin) but only as long as they occupy and till it (la mit en valeur in French). The right to dispose of unoccupied land belongs to the state and the local authority (usually a chief). The local social contract as we observe it in conflict and post-conflict countries depends very little on the delivery of 'development' services but instead relies on the perception of local citizens as to whether they are being provided with justice, which means both (a) access to land for the purposes of production, and (b) local order that is balanced and not unduly oppressive, especially that judicial fines are in line with local income possibilities.?

The traditional authority-holder at the base typically is not representative of the whole community but is the leader of what is considered the 'founding family' (usually through clearing the bush, sometimes by conquest). The 'strangers' who come after the founding family are given permission by its representative to use the land - which creates value and adds to the strength of the community - in return for which the 'stranger' and his descendants are to give tribute and obedience to the scion of the founding family (the chief). So even if the founding social contract might originally have been between a group of relative equals, over time it becomes one between the founding families and the followers (settlers by petition, conquest or slavery).

There are places in Africa where traditional authorities no longer exercise local authority and therefore the occupant is not necessarily from a 'founding family'. In Kenya and eastern Nigeria chiefs were a colonial creation. But in both countries the administrative chiefs conform in other respects to the analysis we provide here. In Tanzania party secretaries replaced chiefs at independence and the determined egalitarianism of its socialist period seems to have spared it from autochthon ('sons of the soil') challenges. In effect they have replaced the chiefs as local authorities. The socialist government of newly independent Mozambique attempted to follow the Tanzanian model of party secretaries but this threat to the still highly legitimate authority of traditional chiefs was one of the causes of the civil war there (Manning 1997).

One of the tensions underlying the local social contract in most of rural Africa is that the land 
Illustrative vignettes of community governance

\section{Southern Sierra Leone}

The many paramount chiefs are elected for life by representatives of local taxpayers. All resident adults are eligible to serve as electors but only descendants of the founding family are eligible for selection. The paramount chief in Shenge is an elderly woman who had a distinguished career in education. But to be elected she had her elected brother deposed by the courts on the grounds that he had been only adopted into the founding family (Vincent 2012).

\section{Eastern Congo}

Rwandaphone pastoralists were present in the Congo's South Kivu Province by the late nineteenth century, before Belgian colonial occupation. Local acceptance of their being there was based on their providing tribute to the Bami (kings) of the already present Babembe, Bavira and Bafulero, payment of which was abrogated in the 1920s. The right to determine who is 'present' on their land remains an important symbolic issue for the 'autochthonous' groups as it relates to the (Rwandaphone) Banyamulenge and has been a subject of occasional violent conflict since the Mulele uprising of the 1960s (Vlassenroot 2002). Babembe land, for example, is not scarce, but the Banyamulenge are pastoralists and come from the high plateau into the former's cultivated fields in the June-September dry season. A fee for this presence has now been negotiated by a political officer from the UN peacekeeping mission MONUSCO, and the problem therefore should be solved. But the Babembe elite continue to want the Banyamulenge to acknowledge symbolically that the land belongs to the Babembe, just as it is important to the Banyamulenge that they be recognised as having become genuine indigines through the state's granting their territory a separate administrative status (Mushi 2012).

\section{Somalia}

For Somalis the primary provider of personal security is the diya-paying group, which comprises about 100 adult males and which negotiates compensation (or exacts revenge) for torts committed on or by outsiders. Islamic courts supplement this tit-for-tat justice and are especially important for business contracts. Thus even in Somaliland and Puntland most justice is delivered by non-governmental institutions, giving both clan and Islam centrality to Somali systems of legitimate governance (Leonard and Samantar 2011).

frontier is now largely closed, so that in many places these immigrant families have come to be seen as competitors, not as contributors to the welfare of the founders. There are two types of this conflict - the first, where the settlers have blended into the original community culturally but still retain a subordinate place; the second, where they retain their cultural distinctness, in which case the conflict takes the form of autochthony (a clash over who has the right of priority because of original settlement - the 'sons of the soil'). The second sometimes arises from state intervention to grant group's or individual's land rights in areas where locals regard them as outsiders. Parts of Sierra Leone illustrate the first type of conflict, as the sons of subordinate families now have difficulty getting farms on which they can grow permanent crops (without which they also can't support their wives) and this led them to provide early support for the civil war there (Jackson 2006; Richards 1998). Congo's South Kivu (Vlassenroot 2002) and western Côte d'Ivoire (Boone 2009; Allouche and Zadi Zadi, this IDS Bulletin) illustrate the variant of the second type where there has been initial local consent, while North Kivu and Kenya's central Rift Valley are examples of earlier state interventions. Both of the latter two variants have fuelled virulent xenophobic appeals to the 'true' locals (i.e. the descendants of the first settlers). In western Côte d'Ivoire the perception of young 'sons of the soil' is that chiefs failed to protect adequately their rights to land in their communities, which undermined traditional authority. The consequence was that in this situation the chiefs were less able to contain inter-ethnic conflict in the rural areas of the west than the central state officials in the 
nearby towns. Here, then, we see the importance of the community-level social contract because it had been weakened. In Somalia the concepts of descent and clanship by adoption are present but ownership is recognised as fluid and subject to conflict, negotiation and contract - which in some ways is less subject to larger-scale violent conflict than the other two.

The cultural and institutional patterns created by the rural social contract are carried over into the cities as well. In urban Bukavu and Uvira (South Kivu), in the absence of strong policing and with simmering rural conflict, we observed that insecure ethnic groups have tended to consolidate in exclusive neighbourhoods. During periods of conflict, groups also organise their own collective night-watch security. Mutualités have developed for all the significant groups in the multi-ethnic towns. These have elected officers (and thus break with the traditional administration practice of appointment by descent). Intra-communal disputes are judged by committees of the 'wise' (sages) and inter-communal ones are negotiated by the officers between mutualités. Those who refuse to be bound by their community's decisions will be ostracised by it, thereby losing its protection and influence, which can be very dangerous for the lone individual. The pattern that has evolved of kinship-based protection, collective decision-making in a more consensual mode, and intergroup negotiation is very similar to the diya-paying ${ }^{8}$ group and clan governance processes that have survived or been revived in Somalia (Leonard and Samantar 2011).

The more difficult conflicts in Africa become rooted in disputes over these intra-local contracts. The inter-area conflicts, which are played out on the national stage, are more easily managed by negotiation and division of 'spoils'. (Examples of both types of conflict and the differences in handling them are evident in Kenya and Nigeria.) Note that these intra-local conflicts rarely threaten state boundaries, as that is not the level at which the intense conflicts lie. Severine Autesserre stresses peacekeepers in conflict states need to address conflicts at this local level, as they sustain the larger, more internationally visible ones that are directly implicated in state breakdown (Autesserre 2007, 2010).

The local social contract remains hugely important even when its terms are being somewhat renegotiated. In eastern Congo, Mozambique and Sierra Leone many chiefs were killed during their civil wars and most of the more senior ones fled the rural areas. Some of these chiefs (more so the Bami in Kivu, Congo than their equivalent paramount chiefs in Sierra Leone) have not returned to their rural residences after the war, which has weakened their legitimacy. Customary tribunals also are not as active in Congo and Sierra Leone as they were before the war. The fact that the customary tribunal judges depend on fees and fines for their income increasingly has led to their being seen as corrupt - or at least biased..$^{9}$ Alternative, nongovernmental dispute resolution services, sometimes tied to the enforcement potential of the magistrates' courts, are becoming more prominent. ${ }^{10}$ Thus the chiefs are less relevant in adjudication now and their legitimacy is somewhat diminished. Nonetheless, it is striking that in Congo and Sierra Leone the role of traditional chief was quickly re-established after the wars and its fundamental legitimacy is not challenged at any level. In Mozambique, where the government had wanted to displace the chiefs, one of the rationales for 'bringing them back' was to help re-establish order and it was strongly supported by women's groups (paradoxically as 'tradition' is patriarchial, but it makes sense because they are the first victims, at home and outside of the home). Chiefs continue to control land allocation and only rarely have men who led self-defence militias during the wars been able to challenge their leadership more generally. (In Mozambique, rebel RENAMO $^{11}$ has been able to gain a role in parliament, but with the support of the chiefs with which they were most closely allied during the civil war.) The social system of the Somalis is non-hierarchical and the title of 'elder' is enjoyed by all adult men in a clan diya-paying group. The continued civil wars have made the diya-paying groups less egalitarian, as the patronage of wealthy businessmen and the militia leaders they support has intruded. But the diya-paying groups themselves have become fundamental again to the security of almost all Somalis. So in all four countries the operation of the local social contract is being renegotiated but not its existence.

In all four countries we see traditional authorities renegotiating their role by also participating in the competition for control of the modern state. In the former Somalia, 
traditional structures of governance and their leading elders have been involved in negotiating successor polities. Their role was particularly central in Somaliland and these elders were appointed to an upper house of its legislature. Similarly, in Puntland these traditional structures continue to select all members of the legislature. On the other hand many elders were perceived as having been bought in the establishment of the Transitional Federal Government of Somalia and were discredited as a result (Leonard and Samantar 2011). The neglect of traditional governance structures in the centre and south of Somalia seems to be a major factor in the failure to re-establish order there and in the growth in competition from political Islamists (Leonard and Samantar, this IDS Bulletin).

In Sierra Leone democratically elected district councils were recreated after the civil war, probably with the intention of diminishing the authority of the chiefs, whose failing in some regions were seen as having contributed to the conflict. A change in national government has led to increased influence for the chiefs, however, and election to district councils and the national parliament is strongly influenced by the endorsements of chiefs.

In South Kivu (DRG), although the power of traditional chiefs is still respected, there are a number of new leaders who are developing new venues of power attached to positions within a larger polity and this has brought many traditional chiefs to reconsider their role and to use it in order to provide new venues for themselves, their offspring or closely related family members. Chiefs seeking to reposition themselves by capitalising on their traditional authority either can compete directly with these new leaders for elective or appointive positions in the provincial or national legislatures, or they can strike bargains to influence the votes of their subjects. It is hard (even if not impossible) for someone to be elected without the backing of his/her communal base, which is heavily influenced by verbal signals from the traditional chiefs.

In all four countries (as generally in Africa) elected representatives are seen as the ambassadors of their communities (Leonard 2009). No matter whether the local authorities are 'kingmakers' or clients and whether their position is traditional, appointive or democratic, they powerfully mediate the relationship between average citizens and the state, preserving key aspects of the traditional twostage social contract.

Mahmood Mamdani in Citizen and Subject (Mamdani 1996) implies that we should be moving away from these local social contracts and embracing (the French Revolution) concept of national citizenship. We are inclined to think this is ahistorical, since local-level social contracts persisted everywhere in the world, including the early industrialising world, until at least 1800. It is true that most Africans today see themselves as having an allegiance to their state (even if not always its regime) but this is in addition to their local allegiance and is still most often mediated operationally through the local social contract. The challenge therefore is not to end local social contracts but instead to make local governance more responsive and effective without challenging the deep residual legitimacy the traditional authorities have in most localities. At least in post-conflict situations, elected local governments and appointed magistrates' courts may be appropriate but they cannot replace the chiefs. The former two can be as corrupt as the latter and elected representatives rely too heavily on chiefs to mobilise electoral support.

Reform of traditional administration, not its displacement, is probably in order in post-conflict situations. Three related possibilities occur to us. First, all local adults might be permitted to elect their chiefs from among the many descendants of the ruling lineage. (This is the Sierra Leone practice, unlike that of Congo where the successor is the child effectively designated by the preceding chief and confirmed by the provincial government. The Somalis do not have chiefs. In Mozambique tradition and party still contend for local leadership in a hybrid system, though the former is now accepted by the government.) Second, chiefs might be asked to renew their mandate every, say, ten years by standing for re-election. (Sierra Leone chiefs serve for life. Congolese chiefs can be removed by the state for malfeasance, but of course this is not a renewal of a local mandate.) Both of these practices would make traditional administration more accountable to those it serves (and therefore less likely to be exploitative) and would help to weed out those who have become old or have proved 
incompetent. Third, the practice of chiefs and customary judges deriving their incomes from the fees and fines they charge for their decisions needs to change. ${ }^{12}$ This practice exacerbates the already prevalent problem of corruption and enhances the perception that local governance is biased. To achieve this, however, government revenues need to be separated from the incomes of governing personnel - one of the classic steps toward modern bureaucracy that Weber chronicled (Weber 1967). Fourth, throughout Africa, wherever land is becoming scarce, the arbitrariness with which chiefs often allocate it weakens the effectiveness of this critical link in local governance, particularly with young men. But in conflict situations (from strong states like Côte d'Ivoire and Kenya through to the weaker ones of Congo, Sierra Leone and Somalia) central management of the closing land frontier has often been worse and thus is a challenge to governance at all levels.

In practice, Somalia has already adopted the first two points, as leadership of the diya-paying group is not hierarchical and most Islamic Sharia court judges are not hereditary. Nor are Sharia courts seen as being as corrupt as other government offices. Thus non-state governance has been resilient in Somalia and movements based on Sharia have special appeal there (Leonard and Samantar, this IDS Bulletin and 2011).

\section{The military bargain}

The effective agreement between an African country's military and its governing regime (and hence the state) is the most problematic and unstable of the four pacts underlying state security. Coups have been notoriously common in independent sub-Saharan Africa. Civilian leaders have found it hard to create bonds of legitimacy with militaries; the result has been not social contracts but bargains of temporary convenience. Even before the rise of the modern state in Europe the identity of military officers there was separate from that of villagers and was closely tied to that of superordinate political authorities. Thus European states and proto-states enjoyed a residual legitimacy from their militaries, particularly in the face of peasant uprisings. The loyalty of the majority of African militaries to their presidents is more likely to be ethnic and based on immediate material advantage. Of course there are exceptions: the presidents of Ethiopia, Rwanda and Uganda came to power at the head of rebel armies. In Tanzania President Nyerere instituted universal six-month military service, so that career officers command only conscripts (who are driven by civilian concepts of loyalty to the state). The Kenyan military seems to have concluded from its participation in United Nations peacekeeping missions that military interventions in politics are always disastrous; and the Nigerian army developed an identity with the state through defence of its unity in the country's painful civil war and is kept in check now by the widespread view that military rule was a failure.

In the DRC, Sierra Leone and Somalia, however, the civil wars were prompted at least in part by military predation and incompetence. In all three, the government was unable to pay either the army or the police an adequate salary and they proceeded to live off the communities where they were posted - which made them militarily ineffective as well. It is an error to see the military in a failing state as an instrument for the provision of security to citizens. In fact in conditions of instability in Africa, army and police instead tend to be predatory - in which case it may or may not be possible for local authorities to make a purely local supplementary contract with them.

In Congo it is quite explicit in the constitution and law that even the police are concerned with the security of the state, not the population (Nlandu 2012). In eastern Congo the situation is even more extreme. What began as a Rwandan invasion to root out the Rwandan Hutu forces that carried out the genocide and threatened the country from nearby refugee camps in the DRC evolved into an occupation of North and South Kivu by a Rwandaphone, even if nominally Congolese, national army. This is not the place to describe the complicated process by which this took place. But Congolese Hutu came to be combined with the Tutsi in the part of the newly integrated Congo army stationed in North and South Kivu and the two turned their attention from the Hutu genocidaires to the local Maï Maï rebels who have consistently resisted the Rwandan invasion. The presence of this army thus exacerbated rather than solved the local security problem and served to delegitimate the national government and UN peacekeeping forces (MONUSCO), which are seen locally as having condoned this development (Mushi 2012). 
The fiction that this Rwandaphone army was serving the Congo has now disintegrated and the former has returned to the status of a militia and is now fighting both the Congolese army (FARDG - Forces Armées de la RDC [Armed Forces of the DRC]) and MONUSCO.

The more general issue is the relationship that the army and police have with the populations in the areas they 'serve'. These aspirants to a 'monopoly over the exercise of legitimate violence' (to use another concept from Weber) in failing states actually are rarely paid properly or on time and thus must derive their incomes from local resources if they and their families are to survive. In the worst instances they simply plunder the locals without limit. In Sierra Leone people consistently spoke disparagingly of the predation of the 'sobels', soldiers who had joined the rebels against the government. In Kivu local chiefs optimally negotiate an agreement with the army and police that the community will provision them as long as they don't otherwise impose on the people. In between are soldiers and police who don't murder or rape locals and take only what they really need. (Congolese informants speak of the latter type of predation as 'well disciplined'.) We found several instances in Kivu where 'living off the land' created severe local tensions and petitions from communities that the army be removed from their areas (because they found it a source of insecurity, not protection). The chiefs who negotiated local provisioning essentially have adopted an ancient practice - as paying armies (rather than having them live off enemy land) is no more than a century and a half old anywhere in the world. One of the American grievances in its revolutionary war was the British practice of 'quartering' individual soldiers abroad on specific families/households, who then were responsible for their room and board. Similarly, Napoleon expected his armies to 'live off the land' in the countries he conquered.

Such 'quartering' is an unsatisfactory practice, however, as it was for Napoleon in Spain and for the British in the American colonies. Proper provisioning through the national budget is much to be preferred. This can be expensive, however, particularly in the aftermath of a civil war. In Somaliland approximately 70 per cent of the government budget goes to its army, which is the remnant of the forces that won the country's independence in 1991.
Provisioning and reorienting the military and police has been easier in Sierra Leone, as the original army was completely decommissioned after it joined the rebels and its replacement was trained and financed by the British. Similarly the police in Sierra Leone were reformed with British help to orient them to the protection rather than control of the population (Charley and M'Cormack 2011). But even when the police and army cease being predators, the major instrument of local order (including in Mozambique) is through communal authority. National police and army can keep others from predating, which does improve local security but only by stabilising the predation. They are too sparse on the ground to create full security against local crime. A major issue troubling both the DRC and Sierra Leone is that the 'customary police' of the traditional local authorities are not being financed any longer and therefore are not effective.

\section{The international bargain}

In practice, weak sub-Saharan African countries experience a fourth agreement with the state as well, one that generally is essential to the other three but is destabilising to them as well. Poor countries lack sufficient domestic finances for the roads, health and education that their communities expect in their social contract with the state and their governments also will strain to pay the salaries of their civil and military services without international development assistance.

Many failed states in Africa have been infected as well with conflicts from their neighbours and need regional and 'Northern' assistance with their attempts to find peace. These forms of aid in effect are bargains and come at a price.

First, the various donors have their own agendas. Some are very much driven by their own domestic interests, such as Eritrea, Ethiopia, Kenya and the USA in Somalia and Burundi, Rwanda and Uganda in eastern Congo. Others are more selfless, such as the UK and Nigeria in Sierra Leone or the UN in all three. Even the benign agendas may be discordant with local priorities, however. For example, the desire of Western powers to support the reconstruction of postgenocide Rwanda is in tension with their desire to bring peace to eastern Congo, where Rwandan activities are a core part of the problem.

Thus, second, international military and budget support is likely to have a shorter time horizon 
than the ten years most observers have concluded is necessary for reconstruction (Collier 2007, 2009). And the countries that prove willing to commit troops may have a counterproductive effect, as did Ethiopia in Somalia and Rwanda in Congo.

Third, international efforts at peacekeeping and state reconstruction are focused on national institutions and conflicts. The internationals tend to have a very weak ability to understand and support the resolution of purely local conflicts (which may actually be sustaining the larger ones) or to buttress the reconstruction of effective local governance, as is evident in both eastern Congo and Somalia (Autesserre 2007, 2010; Leonard and Samantar, this IDS Bulletin and 2011; Menkhaus 2006). Relatedly, the rules of engagement for UN peacekeeping forces limit contact with local communities to a few officers and reduce tours of duty to six months, effectively preventing understanding of local realities. Similarly the expatriates who lead donor organisations and control their purse strings rarely stay in-post for more than a few years, so that they too generally don't understand the subtleties of national, much less local, structures of governance.

Fourth, internationals conceive of rights in terms of individuals rather than collectivities. Thus their interventions have a poor 'fit'. The impact can be positive. Women in Sierra Leone are much better off since the war. They paid a terrible price of rape during the war itself, but the postwar reconstruction efforts unleashed a huge amount of female consciousness-raising by NGOs (both local and international) and by the British with the police. The result is that women (at least in the south and east) are much more conscious of their rights today, they are much less willing to accept abuse from their husbands, they are more aggressive about protecting their rights in court and supporting other women in doing so, and the traditional authorities feel (some reluctantly) that they must respect and enforce these new rights. The same efforts are under way in Congo.

None of this is to say that international involvement in conflict and post-conflict situations is unnecessary or generally counterproductive. The huge imbalance between domestic and international military and financial capabilities, however, gives unusual weight to the internationals. But their imperfect understanding of the national context makes their power clumsy and draws attention away from the local levels to which much more attention must be given if the human security of the populations is to be recreated.

\section{Networks}

The prominence of international actors in the sustenance and functioning of post-conflict states raises the question of whether they threaten the integrity of the African state itself. There is no doubt that governance becomes more horizontal and the actors involved are more numerous and financially consequential in a post-conflict situation. International actors also change the policies countries pursue and indirectly make their politics more open. We conclude, however, that they do not threaten the integrity of the state itself.

International donors tend to network with one another around subject matters of common interest. Nonetheless their differing visions and competing interests do create space within which the recipient national government is most often able to influence if not determine an outcome as long as it cares deeply about it and is relatively united itself. Even in the case of Somalia the donors have not been able to coordinate their activities and priorities effectively, despite trying to do so, being located together outside the country in Nairobi, and facing a very weak Somali government (see Schmidt, this IDS Bulletin).

During the period of conflict, the work of humanitarian international NGOs (INGOs) will be coordinated by UNOCHA (UN Office for the Coordination of Humanitarian Assistance), so as to assure fairly good geographic and functional coverage. Local communities and local NGOs come to understand this function of UNOCHA and know to go there to press their needs and the initiatives they would like to undertake.

Humanitarian INGOs themselves do not prioritise community relationships, however. They are there to 'bind up the wounded, feed the starving and shelter the homeless'. Once the crisis of the immediate conflict is gone, they will leave with little or no notice. It is the development INGOs which are there for the long term. 
The development INGOs tend overwhelmingly to operate from strict programmatic priorities, however. National NGOs come to understand these priorities and structure their own programmes accordingly so as to access funding. But then this means that the NGOs also are driven programmatically and are internationally responsive. Communities find it very difficult to identify and understand donor and INGO priorities. Thus we found that in the aftermath of conflict, communities lack networked relationships with all but a few international donors. Even with local NGOs, it is the NGOs that are taking the initiative to establish priorities (as dictated by the international donors financing them).

The major exception to the foregoing generalisation about development INGOs and NGOs are the churches, which are embedded in the communities, have an interest in being responsive to local priorities, often already have a long-established service infrastructure in the communities, and are supported by their own INGOs. ${ }^{13}$

With the exception of the comparatively modest assistance received from or through the churches, communities rely on their elected representatives (sometimes through the local council) to identify potential donors to meet local priorities. These elected positions are held by people with elite backgrounds (by local standards) who are able to negotiate the complexities of the world of donor priorities and bureaucratic procedures. Thus even very substantial overseas development assistance (ODA) flows reinforce rather than undermine the centrality of government in the delivery of services to the citizens. In fact, even in relatively strong African states international donors frequently finance civil servants to deliver services and programmes (Brass 2012). The programmatic content and structure of development programmes are heavily influenced by donor priorities, philosophies and procedures (Johnson 2009) but most often communities experience the services as being provided by the state and they therefore reinforce, rather than undermine, the social contract between the central state and local communities (Brass 2010, 2012).

Of course where local NGOs rather than civil servants mediate the international provision of resources for local services, their leaders may come to compete with government-based elites for local political leadership. So the precise network through which services reach the community will have political and other consequences, even if not for the legitimacy of the state itself. But this is not new, for it was presaged in the colonial period by the competition that schoolteachers gave to chiefs and other traditional authorities (Ita 1972).

Most of these donor-financed NGO leaders have delimited spheres of influence, so that it matters in local politics or in narrow policy domains who they are but not in broader national politics. Again, the major exception here is the churches, which most often do have the national organisations through which to build on their resurrected role as key service providers.

\section{Conclusions}

The classical concept of the social contract leads us astray in our attempts to provide human security in conflict-ridden countries in subSaharan Africa. It causes us to think of bonds of legitimacy between the state and a citizenry of individuals. Instead the foundational social contracts in Africa are between families and their local authorities and between communities and the larger state. Complicating these two contracts are implicit bargains the state has with its military and with the international community.

In addition, the focus of the classical social contract on individuals leads to a liberal set of values that steer us away from the core issues needing attention in African conflicts - the central role that contested community and individual land rights have in the local social contract, the relationship that communities (rather than individuals) have with the state, and the impact that the unstable loyalties of underfunded militaries have directly and indirectly on community security. Montesquieu's 'liberty' and the checks and balance offered by a focus on groups offers a more promising path in state reconstruction (see Leonard, this IDS Bulletin, last article).

Post-conflict systems of governance in Africa have become much more multilevelled and networked than they were in the era immediately following independence. Local systems of governance and the resolution of their problems are key to the restoration of order. 
Furthermore, the severe resource constraints created by violent conflict make international actors central to the imposition of some semblance of peace - a reality that also makes international actors prominent in the networks that provide resources for reconstruction and development throughout the multiple levels of a country's governance system. The presence of internationals in these networks does mean that a country's president does not have the ability to set priorities and control the distribution of resources in the way s/he did in the first two

\section{Notes}

1 Our project also undertook research on these issues in Mozambique, under the direction of Peter Houtzager and Carlos Cuinhane. Unfortunately that work was not quite complete as we went to press but where possible we have drawn on the interim results.

2 For examples of such Hobbesian analysis, see (Beichman 2008; Winter 2004).

3 The terms used to describe countries hovering on the borders of violent internal conflict are unstable and contested internationally. Some members of the international community establish a distinction between a fragile state, a crisis state and a failed state. Moving from less to more seriously challenged countries, fragile states are vulnerable to internal and external shocks, and domestic and international conflicts. A crisis state is characterised by acute stress and the inability of its governing institutions to manage conflict and shocks. The state is threatened by collapse, war and ultimately the formation of a different state, if no actor succeeds in imposing a new ruling order over the territory. The idea of a failed state is more extreme. It is a condition of state collapse in which the state can no longer perform its basic security functions and has no control over its territory and borders. It can no longer reproduce the conditions of its own existence.

4 A fuller consideration of the limits of the classical Western conception of the social contract when applied to African conflict states is found in Leonard and Samantar (2011).

5 Of course if we were to consider the functions of the state beyond security, the number of contracts might be extended almost to infinity, depending on our level of analysis. The classic work of Barnard (1968 [1938]) as extended by March and Simon (1958) sees all decades of independence. As a result it is possible for local leaders, professionals, national NGOs and churches to challenge the president over matters of policy and politics in ways that they could not in the early independence era. But we find that these new or revitalised networks do not challenge the state as an institution itself. Ultimately the key links in these networks are being provided by individuals and organisations that are embedded in the state and will not challenge its existence, unity or effectiveness.

work in and for organisations as based on a quasi-contractual balance of inducements and contributions.

6 Rousseau gives more credence to people as social creatures whereas Hobbes' analysis is narrowly individualist (O’Hagen 1999; Tuck 1989; Wokler 2001). However, even Rousseau does not give the importance to community that is necessary in Africa. Ibn Khaldun, the fourteenth century Arab philosopher, comes closest (Issawi 1987).

7 Traditional authorities in late colonial and wellfunctioning independent states generally have been quite active on development matters and surely this is an important part of their social contract with their communities. But in conditions of conflict the terms of exchange in the local social contract seem to have reverted to these more basic aspects of governance.

8 Diya groups are made up of about 100 adult males in a sub-lineage who exact and pay compensation for torts committed against and by group members (Lewis 1999 [1961]). Such use of ascriptive ties for security and advantage seems common when civil war forces a breakdown in formal governance structures.

9 Related evidence for Mozambique is found in Kyed (2009a and b) and Workman (2011).

10 A similar development in Ghana is reported by Crook et al. (2010).

11 Mozambican National Resistance (Resistência Nacional Moçambicana).

12 In the DRC fees collected for judgements belong to a decentralised entity (the chefferie or collectivité). The Mwami, as the head of the collectivity, is supposed to receive a wage. Of course the management of fees and taxes collected by the collectivity is patrimonial since the Mwami effectively controls how its revenues are spent and these are used to pay his salary. When the Mwami has no more land to sell or 
other personal resources and when he no longer receives gifts from his prominent subjects, he may end up living like a commoner

\section{References}

Autesserre, Séverine (2010) The Trouble with the Congo: Local Violence and the Failure of International Peacebuilding, Cambridge: Cambridge University Press

Autesserre, Séverine (2007) 'D.R. Congo: Explaining Peace Building Failures, 2003-2006', Review of African Political Economy 34.113: 423-41

Barnard, Chester I. (1968 [1938]) The Functions of the Executive, Cambridge MA: Harvard University Press

Bastian, S. and Luckham, R. (eds) (2003) Can Democracy Be Designed? The Politics of Institutional Choice in Conflict-torn Societies, London: Zed Books

Beichman, Arnold (2008) 'Troubled Nations' Hobbesian World', Washington Times, 16 October

Boone, Catherine (2009) 'Electoral Populism where Property Rights are Weak: Land Politics in Contemporary Sub-Saharan Africa', Comparative Politics 41.2: 183-201

Brass, Jennifer N. (2012) 'Blurring Boundaries: The Integration of NGOs into Governance in Kenya', Governance 25.2: 209-35

Brass, Jennifer (2010) 'Surrogates for Government? NGOs and the State in Kenya', PhD dissertation, Department of Political Science, University of California, Berkeley

Button, Mark E. (2008) Contract, Culture and Citizenship: Transformative Liberalism from Hobbes to Rawls, University Park, Pennsylvania: The Pennsylvania State University Press

Charley, Joseph P. Chris and M'Cormack, Freida Ibiduni (2011) Becoming and Remaining a 'Force for Good'-Reforming the Police in Post-conflict Sierra Leone, IDS Research Report 70, Brighton: IDS

Collier, Paul (2009) Wars, Guns and Votes: Democracy in Dangerous Places, London: The Bodley Head

Collier, Paul (2007) The Bottom Billion: Why the Poorest Countries are Failing and What can be Done About It, Oxford: Oxford University Press

Crook, Richard C.; Asante, Kojo and Brobbey, Victor (2010) Popular Concepts of Justice and Fairness in Ghana: Testing the Legitimacy of New or Hybrid Forms of State Justice, London: Overseas Development Institute if the court revenues are compromised.

13 For example, for the centrality of churches in Congelese education, see De Herdt (2011).

De Herdt, Tom (2011) A La Recherche de l'Etat en $R-D$ Congo: Acteurs et Enjeux d'ue Reconstruction Post-conflit, Paris: Editions L'Harmattan

Etzioni, Amitai (1964) Modern Organizations, Englewood Cliffs NJ: Prentice-Hall

Hobbes, Thomas (1939 [1651]) 'Leviathan, or The Matter, Forme and Power of a Common Wealth Ecclesiastical and Civil', in E.A. Burtt (ed.), The English Philosophers from Bacon to Mill, New York: The Modern Library: 129-234

Issawi, Charles (1987) An Arab Philosophy of History: Selections from the 'Prolegomena' of Ibn Khaldun of Tunis (1332-1406), (trans. by C. Issawi), Princeton: Darwin Press

Ita, Silas (1972) 'The Changing Role Expectations of the Chiefs in Mbere Division: 1900-1971', Department of Government, University of Nairobi

Jackson, Paul (2006) 'Reshuffling an Old Deck of Cards? The Politics of Local Government in Sierra Leone', African Affairs 106.422: 95-111

Jackson, Robert and Rosberg, Carl (1982) 'Why Africa's Weak States Persist: The Empirical and the Juridical in Statehood', World Politics 35.1: 1-24

Johnson, Martha [Gning] (2009) Democracy and the Emergence of Meritocratic Bureaucracies: Explaining Variation within the Senegalese State, Department of Political Science, Berkeley: University of California

Kamara, Abdul R. (2010) Post-War Reconstruction in Failed States: The Case of Sierra Leone, Kusterdingen, Germany: Flower Books Katzenstein, Peter (1996) The Culture of National Security: Norms and Identity in World Politics, New York: Columbia University Press

Kyed, Helene Maria (2009a) 'Community Policing in Post-War Mozambique', Policing and Society 19.4: 354-71

Kyed, Helene Maria (2009b) 'The Politics of Legal Pluralism: State Policies on Legal Pluralism and their Local Dynamics in Mozambique', Journal of Legal Pluralism 59: 87-120

Leonard, David K. (2009) 'Special Issue on Elections and Conflict in Africa', Journal of African Elections 8.1

Leonard, David K. and Samantar, Mohamed S. (2011) 'What Does the Somali Experience Teach Us about the Social Contract and the State?', Development and Change 42.2: 559-84 
Lewis, I.M. (1999 [1961]) A Pastoral Democracy, Oxford, Muenster-Hamburg: James Currey Publishers, International African Institute

Liebermann, Evan (2003) Race and Regionalism in the Politics of Taxation in Brazil and South Africa, Cambridge: Cambridge University Press

Little, Peter D. (2003) Somalia: Economy Without State, Edinburgh: International African Institute

Mamdani, Mahmood (1996) Citizen and Subject: Contemporary Africa and the Legacy of Late Colonialism, Princeton: Princeton University Press

Manning, Carrie L. (1997) Democratic Transition in Mozambique, 1992-1995: Beginning at the End?, Department of Political Science, Berkeley: University of California

Manor, J. (ed.) (2007) Aid That Works: Successful Development Strategies in Fragile States, Washington DC: World Bank

March, James and Simon, Herbert (1958) Organizations, New York: John Wiley

Menkhaus, Ken (2006) 'Governance without Government in Somalia', International Security 31.3: 74-106

Mushi, Ferdinand Mugumo (2012) Insecurity and Local Governance in Congo's South Kivu, IDS Research Report 74, Brighton: IDS

Nlandu, Thierry M. (2012) Mapping Police Services in the Democratic Republic of Congo: Institutional Interactions at Central, Provincial and Local Levels, IDS Research Report 71, Brighton: IDS

O’Hagen, Timothy (1999) Rousseau, London: Routledge

OCDE (2008) Concepts et Dilemmes pour le Renforcement de l'Etat dan les Situation de Fragilité,
Paris: L'Organisation de Coopération et de Développement Economiques

Oliver, Roland and Fage, J.D. (1966) A Short History of Africa, Baltimore: Penguin Books

Prunier, Gerard (2009) From Genocide to Continental War: The 'Congolese' Conflict and the Crisis of Contemporary Africa, London: Hurst

Richards, Paul (1998) Fighting for the Rain Forest, Oxford: James Currey

Tuck, Richard (1989) Hobbes: A Very Short Introduction, Oxford: Oxford University Press

Vincent, James B.M. (2012) A Village-Up View of Sierra Leone's Civil War and Reconstruction: Multilayered and Networked Governance, IDS Research Report 75, Brighton: IDS

Vlassenroot, Koen (2002) 'Citizenship, Identity Formation and Conflict in South Kivu: The Case of the Banyamulenge', Review of African Political Economy 29.93: 499-516

Weber, Max (1967) 'Bureaucracy', in H.H. Gerth and C.W. Mills (eds), From Max Weber: Essays in Sociolgy, London: Routledge: 196-204

Weber, Max (1947) The Theory of Social and Economic Organization, (trans. by A.M. Henderson and T Parsons), New York: The Free Press of Glencoe

Winter, Joseph (2004) Living in Somalia's Anarchy, BBC News, 18 November

Wokler, Robert (2001) Rousseau: A Very Short Introduction, Oxford: Oxford University Press Workman, Anna (2011) Under Pressure: Survivalist Chiefs in Post-War Makeni, Sierra Leone, Washington DG: African Studies Association Young, Crawford and Turner, Thomas (1985) The Rise and Decline of the Zairian State, Madison: University of Wisconsin Press 